\title{
AC 2007-2126: USE OF QFD IN THE ASSESSMENT OF COURSE ACTIVITIES FOR LEARNING OUTCOMES
}

\section{Zbigniew Prusak, Central Connecticut State University}

Dr. Zbigniew Prusak is a Professor in the Engineering Department at Central Connecticut State University in New Britain, CT. He teaches courses in Mechanical and Manufacturing Engineering Technology and Mechanical Engineering programs. He has over 10 years of international industrial and research experience in the fields of precision manufacturing, design of mechanical systems and metrology. Dr. Prusak received M.S. Mechanical Engineering from Technical University of Krakow and his Ph.D. in Mechanical Engineering from University of Connecticut. E-mail: PrusakZ@ccsu.edu 


\title{
Use of QFD in Assessment of Course Activities for Learning Outcomes
}

\author{
Zbigniew Prusak \\ Central Connecticut State University
}

\begin{abstract}
This paper describes the principles of Quality Function Deployment (QFD) used in the assessment of various student activities pursued during both classroom and laboratory instruction. Twenty two different types of student activities were analyzed for their contribution toward fulfillment of thirty learning outcomes. Some of the learning outcomes considered in the presented analysis were identified by Engineering Technology faculty for program assessment purposes. Additionally, there are also other outcomes that were considered by both faculty and members of the Engineering Technology Industrial Advisory Board during the development stage of the program assessment process. In two senior level courses dealing with subjects of engineering design and manufacturing processes, each type of student activity was also assessed in terms of its level according to Bloom's taxonomy. Various assessment methods and observation are utilized in these courses to evaluate students' performance. Design projects, concept generation, individual formal presentations, information search and forensic studies proved to be the most universal activities, developing a wide range of professional skills.

After the initial analysis, for the purpose of feasibility of the assessment process, this large number of skills was reduced to a manageable number and grouped into ten learning outcomes. The ten outcomes became the subject of the formally accepted assessment process for Engineering Technology programs at CCSU.
\end{abstract}

\section{Introduction}

Quality Function Deployment (QFD) technique parallels engineering procedures used for establishing and examining product and process specifications and performances ${ }^{1,2}$. Developed in 1970's in Japan and used in Kobe Shipyard of Mitsubishi Heavy Industries, QFD methodology stemmed from quality improvement tables and was originally used for development of new products ${ }^{3}$ (more details about past, present and future of QFD can be found in paper by Akao ${ }^{4}$ ). However, QFD is also a technique that helps in capturing, organizing and systematizing present knowledge about a product or process with a view of increasing the knowledge and making necessary improvements to meet future challenges ${ }^{3,5,6}$. It is "the only comprehensive quality system aimed specifically at satisfying the customer" 7 . QFD uses voice of customer (VOC) and technical characteristics of a product or process as inputs. Using these two groups of inputs: VOC called also Wants or Needs or Whats and technical characteristics called also Hows, QFD study also aims at establishing relationships between the two groups. Strength of each relationship between each Want and each How is assessed according to degree of how a customer's want is influenced by a technical characteristic. Each relationship is assessed for its existence on lack thereof ${ }^{8}$, or more commonly a degree of strength of relationship is rated to have one of four levels: strong, medium, weak and negligible. To illustrate the degree of relationship in QFD matrix, most authors use symbols, some use symbols 
and/or numerical values to quantify other outcomes of QFD study. Most often used values are: strong $=9$, medium $=3$, weak $=1$, negligible $=0{ }^{9,10}$; although values of $9,5,3$ and 0 respectively are used by some ${ }^{11}$. Application of QFD process ranges from translation of customers' needs into a set of specifications for a new product, defining its feasibility, examination of Wants vs. Hows relationships in existing products, benchmarking and improvement efforts.

QFD can also be utilized in education for rigorous examination of existing programs. Wants are knowledge and skills wanted by employers. They are established by engineering faculty, Industrial Advisory Board (IAB) and discipline-related professional societies. Hows can be described as courses, learning modules, topics and learning activities. The relationships described in this paper illustrate evaluation of learning activities in five courses in Manufacturing Engineering Technology program at Central Connecticut State University.

\section{Program Educational Goals and Means of Achieving Them}

The analysis of the Manufacturing Engineering Technology program involved identification of knowledge and skills required of program graduates. These educational goals of the program became Wants in terms of QFD matrix. Courses required for graduation with BS degree in Manufacturing ET were treated as means of providing the knowledge and skills, hence these became Hows.

\section{Matrix Development}

Deployment of Customer Requirements (VOC) to Production and Quality Controls can be done in a sequence of rigorous five steps ${ }^{3}$ described in Table 1. Each step comprises its own matrix with its own What-How (Wants-Hows) relationships.

Table 1. Deployment of Customer Requirements to Production and Quality Controls.

\begin{tabular}{|c|l|l|l|l|}
\hline & \multicolumn{1}{|c|}{ Deployment step } & \multicolumn{1}{|c|}{ Matrix } & \multicolumn{1}{c|}{ Wants } & \multicolumn{1}{c|}{ Hows } \\
\hline \hline 1 & Product Planning & House of Quality & Customer Requirements & Design Requirements \\
\hline 2 & Product Design I & Design & Design Requirements & Engineering Design \\
\hline 3 & Product Design II & $\begin{array}{l}\text { Product Engineering } \\
\text { Characteristics }\end{array}$ & Engineering Design & $\begin{array}{l}\text { Product Engineering } \\
\text { Characteristics }\end{array}$ \\
\hline 4 & $\begin{array}{l}\text { Process Planning - } \\
\text { Design }\end{array}$ & $\begin{array}{l}\text { Manufacturing and } \\
\text { Purchasing }\end{array}$ & $\begin{array}{l}\text { Product Engineering } \\
\text { Characteristics }\end{array}$ & $\begin{array}{l}\text { Manufacturing and } \\
\text { Purchasing Operations }\end{array}$ \\
\hline 5 & $\begin{array}{l}\text { Process Planning - } \\
\text { Control }\end{array}$ & Control & $\begin{array}{l}\text { Manufacturing and } \\
\text { Purchasing Operations }\end{array}$ & $\begin{array}{l}\text { Production and Quality } \\
\text { Controls }\end{array}$ \\
\hline
\end{tabular}

In real life QFD study not all the steps must be used nor need to be used. The most common, and arguably the one casting longest shadow on the end product under development, is the first step - House of Quality. For purposes of evaluation of existing products, benchmarking products and processes, and other improvement efforts, Customer Requirements can be deployed directly against a higher level of end product related Hows, e.g. Product Engineering Characteristics. In the study described in this paper, learning outcomes (Wants) are deployed 
against learning activities (Hows), which may be loosely equated to deploying customer requirements to manufacturing operations.

\section{Choice of Learning Outcomes for Evaluation}

Learning outcomes that became part of the approved assessment and evaluation process for the purposes of accreditation differ slightly from learning outcomes described in this paper.

Learning outcomes described here are more detailed and serve the purpose of evaluation of learning activities used in teaching process. They stem from examination of vast literature on the subject ${ }^{12-20}$ and professional experience of the author of this paper. They are listed in Table 2. Various authors also use different approaches to the scope of application of their assessment, ranging from a single course ${ }^{21}$, through entire single program ${ }^{18-20}$, to a group of related programs $^{23}$. In his licentiate thesis from 1997, Broberg describes various tools for learners as knowledge workers $^{22}$. One of the noted tools, 'finding internal factors of relevance' is related to the described here continuous improvement efforts with a goal of efficient learning.

Kauffmann et al. described successful application of QFD decision model to prioritize and select courses and curricular content for impact they have on program objectives ${ }^{24}$. A different level of curricular involvement is presented in this paper, which concentrates on learning outcomes and learning activities which are supposed to foster student development in a multitude of ways.

Learning outcomes and procedures identified for the purpose of assessment and evaluation of the entire Manufacturing ET program at CCSU in accordance with TAC of ABET accreditation requirements were described in detail by Lema, Baumann and Prusak ${ }^{23}$. Additionally, there are also other outcomes that were considered by both faculty and members of the Engineering Technology Industrial Advisory Board during the development stage of the assessment process for entire program in accordance to TAC of ABET accreditation requirements. 
Table 2. Learning outcomes assessed for their relevance to learning activities.

\begin{tabular}{|l|l|l|}
\hline $\begin{array}{c}\text { LO } \\
\#\end{array}$ & \multicolumn{1}{|c|}{$\begin{array}{c}\text { Abbreviation code } \\
\text { used in matrix }\end{array}$} & \multicolumn{1}{|c|}{ Desired learning outcome ((knowledge, abilities and skills) } \\
\hline \hline 1. & Engr Sci Know Base & Engineering and scientific knowledge base \\
\hline 2. & Use Know Base & Task-oriented understanding and use of engr. and sci. knowledge base \\
\hline 3. & Comp Tools & $\begin{array}{l}\text { Knowledge and use of computer tools (CAD/CAM, FEA, data } \\
\text { acquisition, data processing and graphing, reporting, presentation, etc. })\end{array}$ \\
\hline 4. & Sketch & Ability to quickly generate hand sketches \\
\hline 5. & Engr Std & Knowledge of pertinent engineering standards \\
\hline 6. & Use Engr Std & Task-oriented understanding and use of pertinent engineering standards \\
\hline 7. & Interdisc Think & Interdisciplinary thinking \\
\hline 8. & Sysmtic Prob Evalu & Systematic and interdisciplinary evaluation of problems \\
\hline 9. & Analy Well-def Prob & Analysis of well-defined problems \\
\hline 10. & Analy Open Prob & Analysis of open-ended problems \\
\hline 11. & Analy Ill-def Prob & Analysis of ill-defined problems \\
\hline 12. & Solv Prob Team & Solving of problems in teams \\
\hline 13. & Org Team Work & Organization of team work \\
\hline 14. & Act Independently & Acting independently \\
\hline 15. & Org Indiv Work & Self-organization \\
\hline 16. & Writ Comm Tech & Written communication with technical people \\
\hline 17. & Verb Comm Tech & Verbal communication with technical people \\
\hline 18. & Writ Comm Non-tech & Written communication with non-technical people \\
\hline 19. & Verb Comm Non-tech & Verbal communication with non-technical people \\
\hline 20. & Comm Diff Culture & Communication with people from different cultures \\
\hline 21. & Persuade Negotiate & Persuasion, negotiation \\
\hline 22. & Info Search & Search for information \\
\hline 23. & Info Reduc Compil & Reduction and compilation of information \\
\hline 24. & Creativity & Creative thinking \\
\hline 25. & Systems Think & Systems thinking \\
\hline 26. & Value Engr & Value engineering \\
\hline 27. & Prof Ethics & Professional ethics \\
\hline 28. & Manners & Personal manners \\
\hline 29. & Work Under Press & Work under pressure \\
\hline 30. & Self Learn & Self learning \\
\hline & & \\
\hline
\end{tabular}

\section{Choice of Evaluated Learning Activities}

Majority of these learning activities are used continuously in five courses required in Manufacturing ET program at CCSU. Some of them were tried for a period of at least 3 semesters and dropped due to a variety of reasons: predominantly time constraints manifested in non-substantial contribution to learning outcomes for significant class time involved or students' study time involved. The five courses and Co-op are described in Table 3. 
Table 3. Learning activities assessed in QFD matrix.

\begin{tabular}{|l|l|l|}
\hline \multicolumn{1}{|c|}{ Course level } & \multicolumn{1}{c|}{ Course name } & \multicolumn{1}{c|}{ Course type } \\
\hline Sophomore & Materials Processing & classroom / lab \\
\hline Junior/Sophomore & Geometric Dimensioning \& Tolerancing & classroom \\
\hline Junior & Computer Aided Planning & classroom / computer lab \\
\hline Senior & Manuf. Process Planning and Estimating & classroom / lab on occasion \\
\hline Senior & Design for Manufacture & classroom / lab on occasion \\
\hline Senior & Industrial Co-op & industry, full time \\
\hline
\end{tabular}

Table 4 provides list of learning activities that are evaluated through QFD matrix relationship for their usefulness in providing high level learning outcomes. Industrial Co-op comprising full time industrial experience is very difficult to assess due to lack of academic control and large variability between Co-op assignments. For these reasons, drawing on hundreds of interviews with students who finished Co-op, two types of Co-op experience were used for the matrix: excellent experience where a students is involved in planned and supervised activities, and poor experience where a student spends most time 'putting down fires' with no clear goals for achievement. As can be expected, majority of Co-op experiences are somewhere in between the two.

Table 4. Learning activities assessed in QFD matrix.

\begin{tabular}{|l|l|l|}
\hline $\begin{array}{c}\text { Act } \\
\#\end{array}$ & \multicolumn{1}{|c|}{$\begin{array}{c}\text { Abbreviation code } \\
\text { used in matrix }\end{array}$} & \\
\hline 1. & Lect & Lecture \\
\hline 2. & Hw & Graded homework \\
\hline 3. & Read & Reading and self study \\
\hline 4. & Quiz & Short quiz \\
\hline 5. & Exam & Exam (midterm, final, etc. $)$ \\
\hline 6. & Comp Lect & Computer lab lecture \\
\hline 7. & Lab Sh Exe & Laboratory hands-on short exercises \\
\hline 8. & Lab Expm Team & Laboratory experimentation - team work \\
\hline 9. & Forens Indiv & Forensic analysis in-class exercises - individual work \\
\hline 10. & Forens Team & Forensic analysis in-class exercises - team work \\
\hline 11. & Des Sh Exe Indiv & Design short exercises in-class - individual work \\
\hline 12. & Des Sh Exe Team & Design short exercises in-class - team work \\
\hline 13. & Des Proj Indiv & Design projects - individual work \\
\hline 14. & Des Proj Team & Design projects - team work \\
\hline 15. & Des Dev Lab Expm & Design and development of new lab experiments \\
\hline 16. & Concept Gener & Concept generation (Brainstorming, Synectics) \\
\hline 17. & Critique & Critique of own work and work of others \\
\hline 18. & Info Search & Information search and compilation assignment \\
\hline 19. & Pres Indiv & Individual presentation \\
\hline 20. & Pres Team & Group presentation \\
\hline 21. & Co-op excell & Industrial Co-op excellent experience \\
\hline 22. & Co-op poor & Industrial Co-op poor experience \\
\hline & & \\
\hline
\end{tabular}




\section{QFD Matrices and Analysis of Results}

Table 5. Deployment of learning outcomes to learning activities - QFD matrix for all courses listed in Table 3.

Codes for Learning Outcomes and for Learning Activities are in Tables 2 and 4 respectively.

Relationship code: $\bullet=$ strong, $\mathbf{O}=$ medium, $\boldsymbol{\Delta}=$ weak, empty cell $=$ negligible .

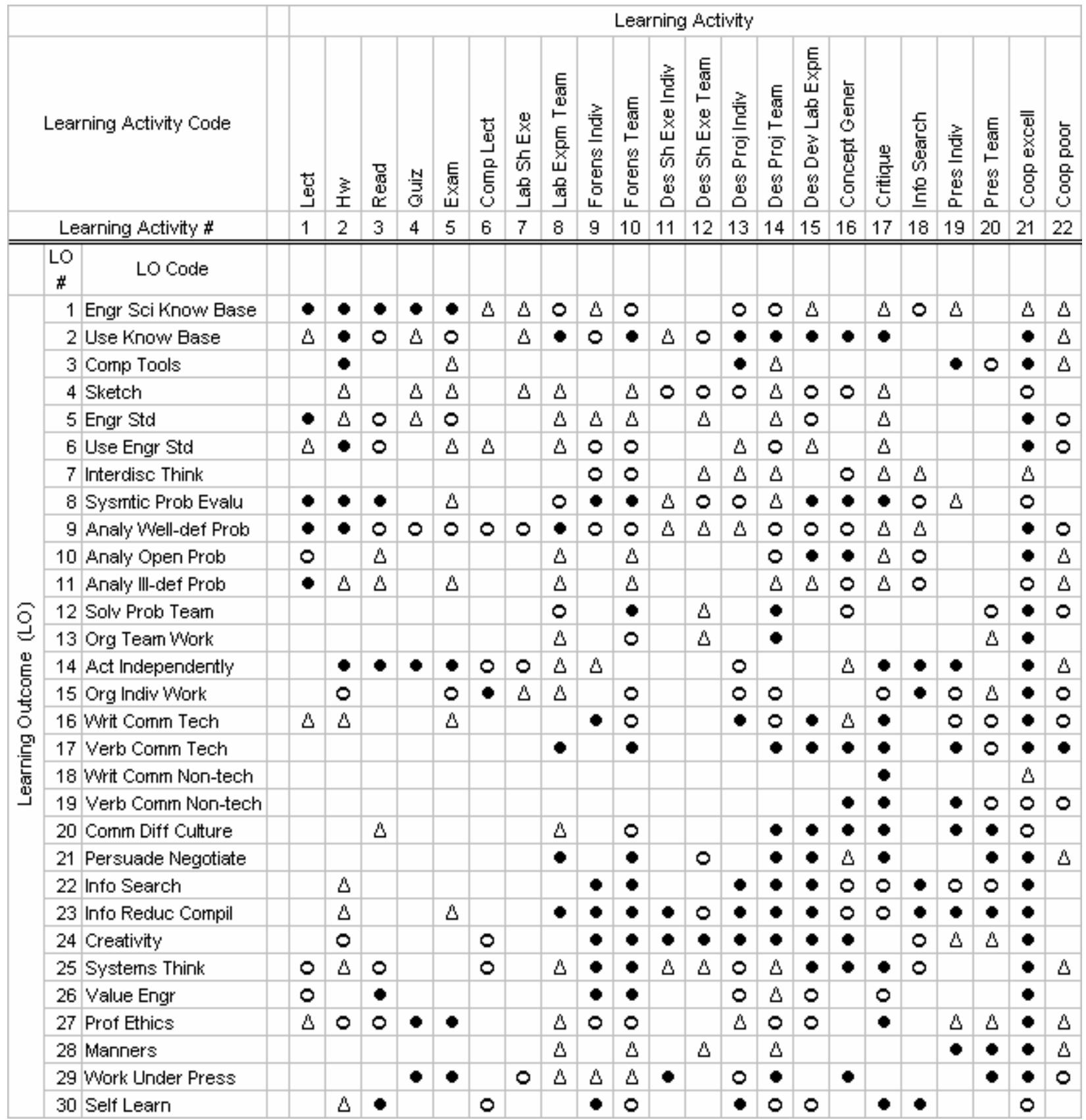


It should be noted that Co-op total strength of relationship is double that of each other learning activity. It was clarified earlier in explanation of Table 4. Most Co-op experiences are somewhere in between the excellent and poor.

Table 6. Comparison of usefulness of learning activities in fulfillment of learning outcomes for all courses listed in Table 3. The higher the number the higher the usefulness. Codes for Learning Activities are in Table 4. Relationship code shown in Table 5 was substituted for calculations with numbers: $\boldsymbol{\bullet}=9=$ strong, $\mathbf{O}=3=$ medium, $\boldsymbol{\Delta}=1=$ weak, empty cell $=0=$ negligible.

\begin{tabular}{|c|c|c|c|c|c|c|c|c|c|c|c|c|c|c|c|c|c|c|c|c|c|c|}
\hline & \multicolumn{22}{|c|}{ Learning Activity } \\
\hline & 荷 & 竞 & 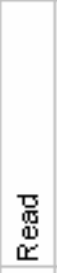 & $\stackrel{\stackrel{N}{F}}{\vec{\sigma}}$ & $\begin{array}{l}\text { 焉 } \\
\text { 品 }\end{array}$ & 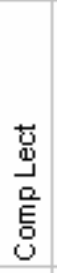 & 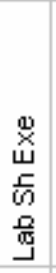 & 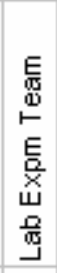 & 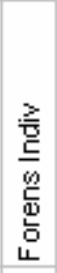 & 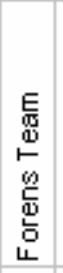 & 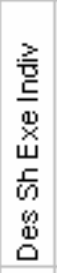 & 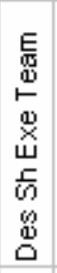 & 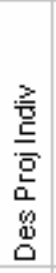 & 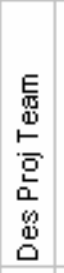 & 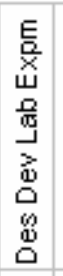 & 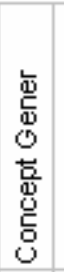 & 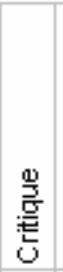 & $\begin{array}{c}\text { 동 } \\
\text { 怘 } \\
0 \\
0 \\
0 \\
\text { 으 }\end{array}$ & 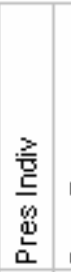 & 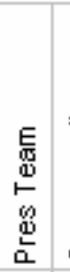 & 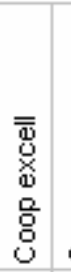 & $\begin{array}{l}\stackrel{5}{g} \\
\stackrel{9}{8}\end{array}$ \\
\hline & 1 & 2 & 3 & 4 & 5 & 6 & 7 & 8 & 9 & 10 & 11 & 12 & 13 & 14 & 15 & 16 & 17 & 18 & 192 & 202 & 212 & 22 \\
\hline $\begin{array}{l}\text { Learning Acitvity } \\
\text { Usefulness } \\
\text { Comparison }\end{array}$ & (19 & 要 & 䍐 & $\bar{~} \bar{y}$ & 点 & $\overline{\underline{9}}$ & ले & $\bar{c}$ & $\overline{\bar{\sigma}}$ & 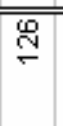 & 志 & $\bar{m}$ & $\overline{\bar{\sigma}}$ & 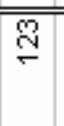 & "ָั & 営 & " & " & 黑 & $\overline{\mathrm{c}}$ & 品 & 产 \\
\hline
\end{tabular}

As explained below Table 5, Co-op score should be viewed to be somewhere between 43 and 210. Its average of 127 should be taken for purposes of comparison with other learning activities. The group of learning activities having highest usefulness in fulfillment of learning outcomes (taking into account 5 courses listed in Table 3) consists of:

- Forensic analysis in-class exercises - team work

- Design projects - team work

- Design and development of new lab experiments

- Concept generation (Brainstorming, Synectics)

- Critique of own work and work of others

Despite their average scores, the traditional rudimentary learning activities (lecture, homework, reading, quiz, exams) are the most useful in preparation of learner's knowledge base and skills of effective use of it. Short design exercises scored low, however their contribution in fostering creative thinking is very substantial. These exercises do not require a substantial allocation of classroom time; therefore can be repeated multiple times, further adding to their usefulness. 
Table 7. Comparison of fulfillment of learning outcomes based on usefulness of learning activities for all courses listed in Table 3. The higher the number the more substantial the fulfillment.

Codes for Learning Activities are in Table 2.

Relationship code shown in Table 5 was substituted for calculations with numbers:

$\boldsymbol{\bullet}=9=$ strong, $\mathbf{O}=3=$ medium, $\Delta=1=$ weak, empty cell $=0=$ negligible.

\begin{tabular}{|c|c|c|c|}
\hline \multicolumn{3}{|c|}{ Learning Activity Code } & 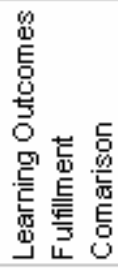 \\
\hline \multicolumn{4}{|c|}{ Learning Activity \# } \\
\hline & $\begin{array}{c}\text { LO } \\
\#\end{array}$ & LO Code & \\
\hline \multirow{30}{*}{ 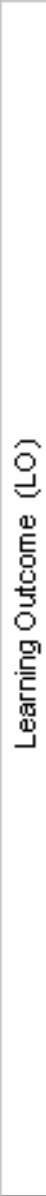 } & & Engr Sci Know Base & 68 \\
\hline & 2 & Use Know Base & 98 \\
\hline & 3 & Comp Tools & 42 \\
\hline & 4 & Sketch & 26 \\
\hline & 5 & Engr Std & 38 \\
\hline & 6 & Use Engr Std & 40 \\
\hline & 7 & Interdisc Think & 15 \\
\hline & 8 & Sysmtic Prob Evalu & 91 \\
\hline & 9 & Analy Well-def Prob & 74 \\
\hline & 10 & Analy Open Prob & 41 \\
\hline & 11 & Analy Ill-def Prob & 27 \\
\hline & 12 & Solv Prob Tearn & 40 \\
\hline & 13 & Org Tearn Work & 24 \\
\hline & 14 & Act Independently & 85 \\
\hline & 15 & Org Indiv Work & 54 \\
\hline & 16 & Writ Comm Tech & 64 \\
\hline & 17 & Verb Comm Tech & 84 \\
\hline & 18 & Writ Comm Non-tech & 10 \\
\hline & 19 & Verb Comm Non-tech & 36 \\
\hline & 20 & Comm Diff Culture & 62 \\
\hline & 21 & Persuade Negotiate & 68 \\
\hline & 22 & Info Search & 76 \\
\hline & 23 & Into Reduc Compil & 110 \\
\hline & 24 & Creativity & 92 \\
\hline & 25 & Systems Think & 75 \\
\hline & 26 & Value Engr & 49 \\
\hline & 27 & Prof Ethics & 60 \\
\hline & 28 & Manners & 32 \\
\hline & 29 & Work Under Press & 75 \\
\hline & 30 & Self Learn & 61 \\
\hline
\end{tabular}

Not surprisingly, learning outcome 'Reduction and compilation of information' came on top as the best fulfilled by the learning activities evaluated. The learning process is about information compilation and reduction even if little self preparation of students is required a lot of spoon feeding is practiced to enhance amount of material covered.

Interdisciplinary thinking, analysis of ill-defined problems, conveying technical ideas using hand sketches, and methodical organization of team work scored poorly. This is not a surprise, since 
these skills either did not make their way to traditional engineering curricula yet or, as in the case of sketching are considered obsolete and were replaced with computer skills. Written and verbal communication with non-technical people does not find emphasis in the five courses considered here, due to the fact that it is emphasized in general education section of program curriculum. Another poor scorer, manners, is expected to be taught even earlier on, during K-12 education and at home.

Tables 8 and 9 illustrate learning activities used in two senior level courses required in Manufacturing ET program. Each activity used in the course is coded for level of its emphasis during the semester. For comparison of usefulness of learning activities, each activity usefulness score (as shown in Table 6) was multiplied by number pertinent to the level of emphasis in each course. For example, Lecture has 58 in Table 6, 9 for level of emphasis in Table 8, hence its score is 522. Bloom's Taxonomy level corresponding to for each learning activity as used in the courses is also shown in Tables 8 and 9.

Table 8. Comparison of usefulness of learning activities used in senior level course Manufacturing Process Planning and Estimating in fulfillment of learning outcomes. The higher the number the higher the usefulness. Codes for Learning Activities are in Table 4. Relationship code shown in Table 5 was substituted for calculations with numbers: $\boldsymbol{0}=9=$ strong, $\mathbf{O}=3=$ medium, $\boldsymbol{\Delta}=1=$ weak, empty cell $=0=$ negligible.

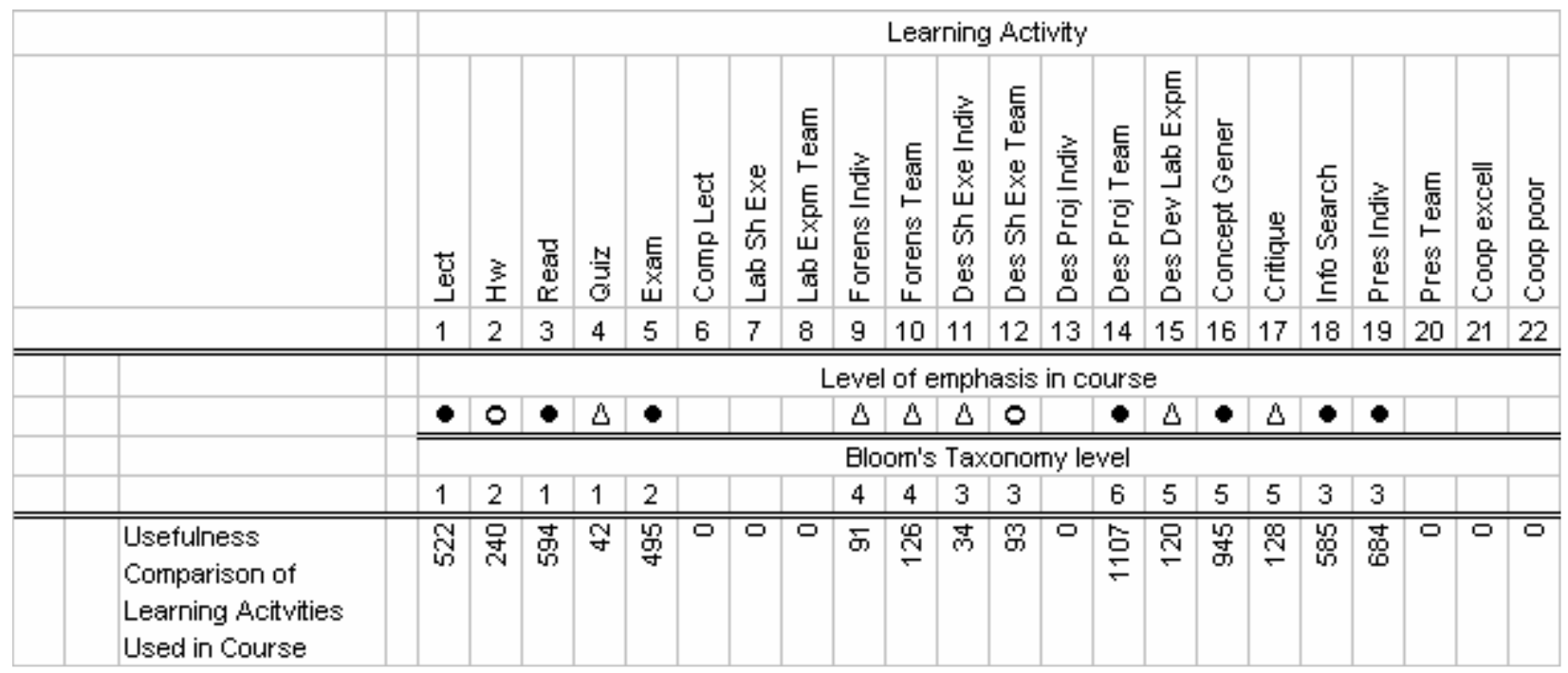

It is noticeable that for both courses summarized in Tables 8 and 9, usefulness of learning activities can be grouped into three categories according to their level of fulfillment of learning objectives. The grouping is base on scores in the bottom row.

- First category of most useful activities comprises: design projects done in teams, and concept generation. 
- Second category comprises: individual presentations, information search compilation and reduction, assigned reading, lecture, exams, and for DFM course forensic analysis exercises done in-class as team work.

- Third category comprises the rest.

These two courses were chosen to provide assessment and evaluation data for continuous improvement efforts. Since these two courses are required in Manufacturing ET and Mechanical ET programs, the data is used also for purpose of TAC of ABET accreditation self study and continuous improvement of both programs (detailed description available in paper by Lema, Baumann and Prusak ${ }^{23}$ ).

Table 9. Comparison of usefulness of learning activities used in senior level course Design for Manufacture in fulfillment of learning outcomes. The higher the number the higher the usefulness.

Codes for Learning Activities are in Table 4.

Relationship code shown in Table 5 was substituted for calculations with numbers: $\boldsymbol{\bullet}=9$ = strong, $\mathbf{O}=3=$ medium, $\boldsymbol{\Delta}=1=$ weak, empty cell $=0=$ negligible.

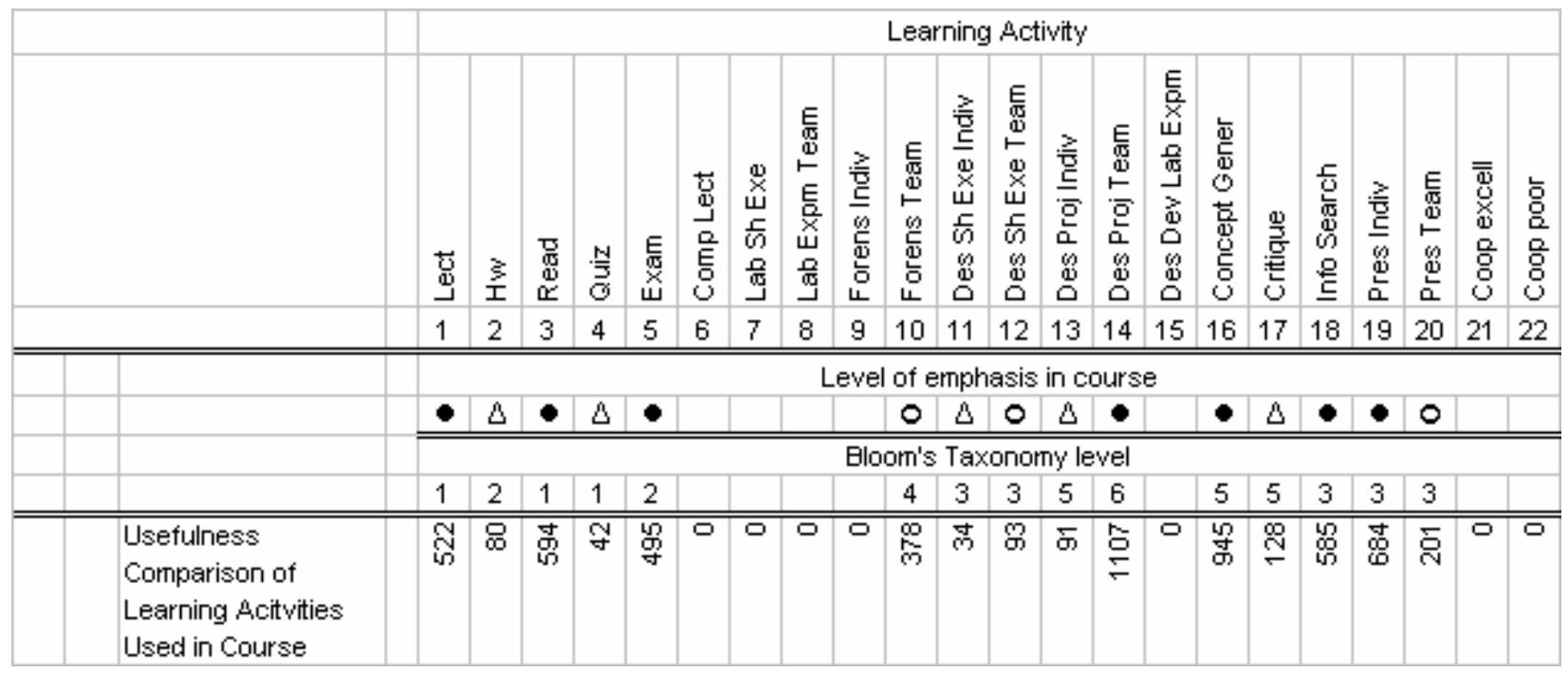

\section{Conclusions}

Design projects done in teams, concept generation, individual formal presentations, information search, compilation and reduction, as well as forensic studies proved to be the most universal activities, developing a wide range of professional skills. Future development plans for both courses envision inclusion of more forensic studies done in teams. That requires gathering of real samples since textbook and video examples almost always lack thorough investigation and follow through with improvement efforts.

Due to a variety of learning activities and assessment methods the two senior level courses described in this paper were chosen to provide assessment and evaluation data for continuous improvement efforts and for TAC of ABET accreditation self study and continuous improvement efforts in Manufacturing ET and Mechanical ET programs. 


\section{Bibliography}

1 Hauser, J., Clausing, D., The House of Quality, Harvard Business Review, vol.66, no.3, 1988, pp.63-73.

2 Urban, G., Hauser, J., Design and Marketing of New Products, Prentice Hall, Englewood Cliffs, NJ, 1993.

3 ReVelle, J.B., Frigon, N.L., Jackson, H.R., From Concept to Customer, Van Nostrand Reinhold, 1995.

4 Akao, Y., QFD: Past, Present and Future, International Symposium on QFD, 1997, Linkopping, Sweden.

5 Ulrich, K.T., Eppinger, S.D., Product Design and Development, McGraw-Hill, New York, NY, 1995.

6 Terninko, J., Step-by-Step QFD. Customer-Driven Product Design, St. Lucie Press, Boca Raton, FL, 1997.

7 Japan Business Consultants, http://www.mazur.net/qfd.htm\#Design\%20for\%20Six\%20Sigma viewed on $12 / 12 / 2006$.

8 Hyman, B., Fundamentals of Engineering Design, Prentice Hall, Upper Saddle River, NJ, 1998.

9 Quality Function Deployment Application Guide, Technicomp, Cleveland, OH, 1989.

10 Dixon, J.R., Poli, C., Engineering Design and Design for Manufacturing, Field Stone Publishers, Conway, MA, 1995.

11 Otto, K.N., Wood, K.L., Product Design, Techniques in Reverse Engineering and New Product Development, Prentice Hall, Upper Saddle River, NJ, 2001.

12 Bahner, B., Report: curricula need product realization, ASME News, March 1996, vol.15, no.10, pp.1,6

13 Prusak, Z., Challenges to Future Engineering Professionals - How to Prepare Students to Face Them, Proceedings of ASEE Annual Conference, June 28- July 1, 1998, Seattle, WA.

14 Prusak, Z., Development of Inventive Skills and Engineering Education - a Global Outlook, Proceedings of International Conference on Engineering Education, July 25-29, 2005, Gliwice, Poland.

15 Incropera, F.P., Fox, R.W., Revising Mechanical Engineering Curriculum: The Implementation Phase, Journal of Engineering Education, vol.85, no.3, 1996, pp.233-238.

16 Prusak, Z., Introduction to Global Engineering: Use of Standards and Cultural Differences, Proceedings of $36^{\text {th }}$ Frontiers in Education Conference, Oct.28-31, 2006, San Diego, CA.

17 Eggert, R., DFM Survey, http://coen.boisestate.edu/REGGERT/DFMA/1indsrvyresults.htm, viewed on $12 / 17 / 2005$

18 Scales, K., Owen, C., Shiohare, S., Leonard, M., Preparing for Program Accreditation Review Under ABET Engineering Criteria 2000: Choosing Outcome Indicators, Journal of Engineering Education, vol.87, no.3, 1998, pp.207-210.

19 Watson, J., An Analysis of the Value of the FE Examination for the Assessment of Student Learning in Engineering And Science Topics, Journal of Engineering Education, vol.87, no.3, 1998, pp.305-311.

20 McGourty, J., Sebastian, C., Swart, W., Developing a Comprehensive Assessment Program for Engineering Education, Journal of Engineering Education, vol.87, no.4, 1998, pp.355-362.

21 Bailey, M., Floersheim, R.B., Ressler, S.J., Course Assessment Plan: A Tool for Integrated Curriculum Management, Journal of Engineering Education, vol.91, no.4, 2002, pp.425-434.

22 Broberg, A., Learners as Knowledge Workers - Some Implications, Journal of Engineering Education, vol.90, no.1, 2001, pp.63-68.

23 Lema, L.F., Baumann, P.F., Prusak, Z., In-common Methodology for Objective- and Outcome-based Programs Assessment, Proceedings of ASEE Annual Conference, June 12-15, 2005, Portland, OR.

24 Kauffmann, P., Fernandez, A., Keating, C., Jacobs, D., Unal, R., Using Quality Function Deployment to Select the Courses and Topics that Enhance Program Effectiveness, Journal of Engineering Education, vol.91, no.2, 2002, pp.231-237. 